\title{
Inhaled corticosteroids reduce growth. Or do they?
}

\author{
P.L.P. Brand
}

\section{Inhaled corticosteroids reduce growth. Or do they? P.L.P. Brand. (C)ERS Journals Ltd 2001.}

ABSTRACT: The class label warning in the United States for inhaled corticosteroids (ICS's) states that these drugs may reduce growth velocity in children. In this paper, the evidence for this warning is reviewed from a clinical point of view.

Children with asthma tend to grow slower than their healthy peers during the prepubertal years because they go into puberty at a later age. However, asthmatic children do achieve a (near) normal adult height. In randomized controlled clinical trials, the use of inhaled beclomethasone, budesonide and fluticasone is associated with a reduced growth during the first months of therapy, in the order of magnitude of approximately $0.5-1.5 \mathrm{~cm} \cdot \mathrm{yr}^{-1}$. It is, however, unlikely that such an effect continues or persists because accumulating evidence shows that asthmatic children, even when they have been treated with ICS for years, attain normal adult height. Individual rare cases have been reported, however, where ICS use was associated with clinically relevant growth suppression.

Inhaled corticosteroids are the most effective therapy available for maintenance treatment of childhood asthma. Fear of reduced growth velocity is based on exceptional cases and not on group data. It should, therefore, not be a reason to withhold or withdraw such highly effective treatment in children with asthma.

Eur Respir J 2001; 17: 287-294.
Isala klinieken/Weezenlanden Hospital, PO Box 10500, 8000 GM, Zwolle, the Netherlands.

Correspondence: P.L.P. Brand, Isala klinieken/Weezenlanden Hospital, PO Box $10500,8000 \mathrm{GM}$, Zwolle, the Netherlands

Fax: +31 384242734

Keywords: Growth

inhaled corticosteroids

review

Received: May 202000

Accepted after revision October 182000
In the summer of 1998, the Pulmonary-Endocrine Drugs Advisory Committee of the American Food and Drug Administration (FDA) convened in Bethesda, USA to review data on the effect of inhaled corticosteroids (ICS's) on growth of children with asthma. The Committee decided by conrevsus to alter the class labelling for all intranasal and inhaled corticosteroids in children to include a precautionary statement that the use of these drugs in recommended doses may be associated with a reduction in growth velocity. This committee decision received widespread attention throughout the world by paediatricians being concerned about the possible side effects of ICS therapy.

At about the same time, a $13 \mathrm{yr}$ old girl with moderately severe asthma, was referred to the present author by a general paediatrician because her growth was reduced during ICS treatment (fig. 1). Four and a half years previously, at the age of 8 , she was started on inhaled beclomethasone dipropionate (BDP) $400 \mu \mathrm{g}$ daily, by dry powder inhaler (DPI), because her asthmatic symptoms were insufficiently controlled on inhaled bronchodilators alone. After she started ICS's, her asthma was well controlled; attempts to reduce the daily dose resulted in recurrence of troublesome nocturnal symptoms. Her mother was very concerned about her daughter's growth ("She's now by far the smallest girl in her class, doctor!") and brought with her a summary of the FDA Committee's report downloaded from the Internet. She requested support for her decision to stop ICS treatment and to start her on another form of anti-inflammatory maintenance therapy.
What are the issues in this case?

Every paediatrician is familiar with cases such as this. Before making a decision on withdrawing or continuing ICS treatment in a case such as this, the evidence on several issues needs to be reviewed (table 1). Then, the applicability of the evidence to the particular case should be addressed; what are the pros and cons of ICS

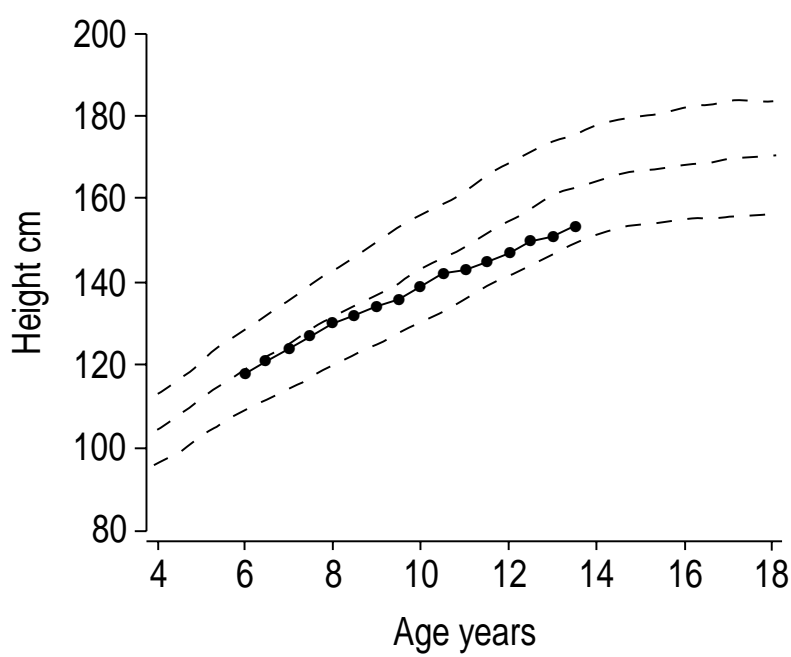

Fig. 1. - Growth curve of Linda the patient, a girl with asthma using inhaled beclomethasone $400 \mu \mathrm{g} \cdot \mathrm{day}^{-1}$ from the age of 8 until she was referred at the age of 13 . The dotted lines represent the normal mean height \pm 2 standard deviations. 
treatment in this child, and how should they be balanced?

\section{What are the effects of corticosteroids on growth in general?}

There is convincing evidence that daily maintenance treatment with systemic corticosteroids reduces growth in children with various diseases [1, 2]. Alternate-day oral corticosteroid therapy is also associated with reduced growth, but to a lesser degree than a daily schedule [3]. The cumulative growth-reducing effect of systemic corticosteroids may amount to more than $10 \mathrm{~cm}$, although many children continue to grow normally even during long-term systemic steroid therapy [4]. Because the risk of growth suppression during treatment with systemic corticosteroids is large, the concern that inhaled corticosteroids might also be growth-suppressive, is understandable [5].

\section{What is the bioavailability of inhaled corticosteroids?}

Inhaled corticosteroids can only reduce growth after they become available systemically. Systemic side effects of ICS's are determined by absorption from the lung and the gut (fig. 2) [6-8]. The amounts of drug that are deposited in the lung and in the oropharynx depend largely on the type of inhaler device being used and on the patient's inhalation technique $[9,10]$. If a spacer device is being used, oropharyngeal deposition is low; the largest proportion of the drug that is not deposited into the lung remains in the spacer $[11,12]$. If a DPI or a metered dose inhaler (MDI) without a spacer is used, a considerable proportion of the inhaled drug (up to $60 \%$ ) is deposited in the oropharynx, swallowed and may thus contribute to systemic availability [13, 14]. Under these circumstances, systemic bioavailability depends on the degree of first-pass inactivation in the liver, which is larger for fluticasone propionate (FP, 99\%) and budesonide (BUD 90\%) than for BDP $(70 \%)$ [15]. Oropharyngeal deposition can be reduced by mouth rinsing [16]. Regardless of the inhalation device and the specific drug inhaled, systemic bioavailability is predominantly determined by the amount of drug deposited into the lung (fig. 2) [9]. Improved lung deposition will, therefore, inevitably lead to increased systemic availability of ICS's. It can be assumed that lung deposition is higher in healthy subjects and in patients with mild asthma, than in patients with more severe airways obstruction [17].

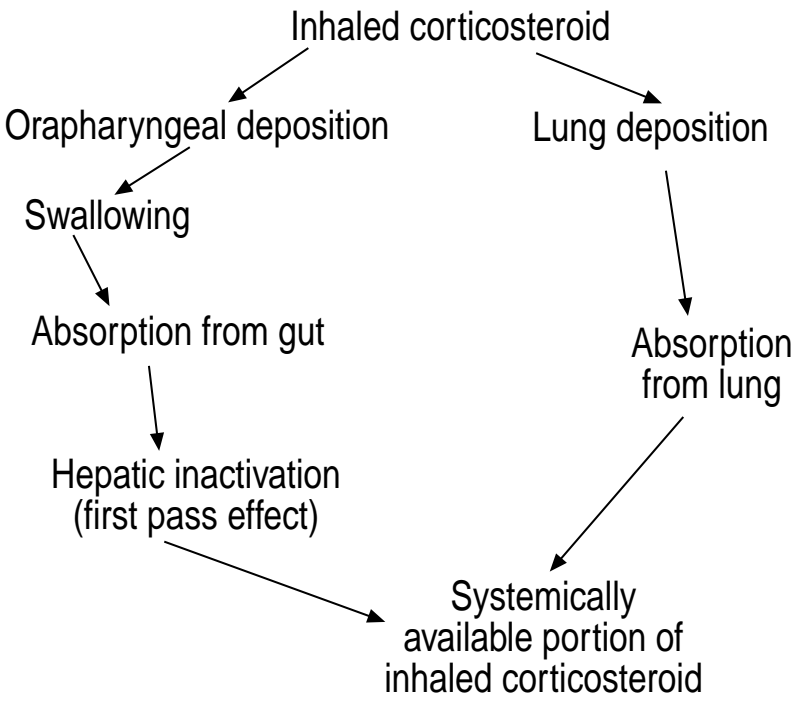

Fig. 2. - Systemic availability of inhaled corticosteroids depends on absorption from gut and lung.

The potential of systemically available ICS's to cause side effects is also determined by their pharmacokinetic properties. FP, being the most lipophilic ICS, not only has the largest corticosteroid receptor affinity, but also has a larger volume of distribution and a longer elimination half-life than other ICS's [18]. This may help to explain why FP causes more adrenal suppression than BUD, in particular during steady state daily dosing [19-22]. During single-dose studies, accumulation of lipophilic compounds does not occur and systemic effects may be less clear [23]. Studies on systemic side effects of ICS's, are therefore best performed during steady state dosing.

\section{What is the dose-effect relationship of inhaled corticosteroids for systemic side effects?}

Both anti-inflammatory and systemic effects of corticosteroids are dose-dependent, but the doseresponse curves of pulmonary and systemic effects differ markedly (fig. 3) [7, 24, 25]. The dose-response curve for pulmonary effects appears to have its steep part at relatively low daily doses, to flatten off towards higher daily doses. For systemic effects, the reverse pattern applies (fig. 3). Although this basic principle applies for all ICS's available today, the exact doseresponse curves may differ between various compounds, and even between different individuals using

Table 1.-Issues in the discussion on the effects of inhaled corticosteroids on growth

What are the effects on growth of corticosteroids in general?

What is the bioavailability of inhaled corticosteroids?

What is the dose-effect relationship of inhaled corticosteroids for systemic side effects?

How do children with asthma grow when they are not treated with inhaled corticosteroids?

What are the effects of inhaled corticosteroids on growth in asthmatic children?

Retrospective studies

Prospective controlled clinical trials

Short-term (weeks)

Medium-term (months)

Long-term (final height) 


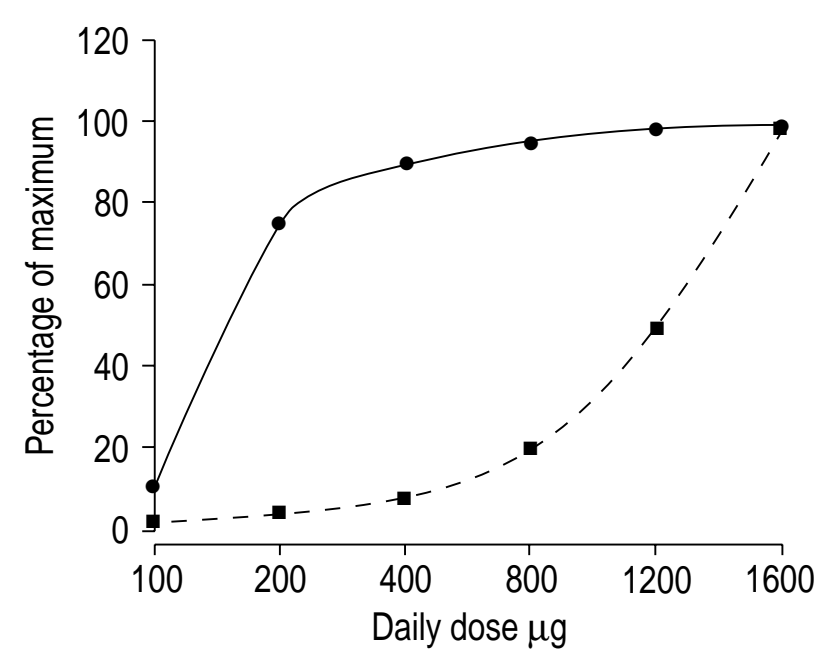

Fig. 3. - Pulmonary anti-inflammatory effects (-) and undesired systemic side effects (---) if inhaled corticosteroids (ICS's) at different daily doses. The figure is intended to illustrate the basic principle of these two different dose-response curves. The curves depicted here belong to a hypothetical ICS; exact values on the $\mathrm{X}$ axis may differ between ICS's and patients.

the same compound [15]. It is likely that genetically determined polymorphism in the glucocorticoid receptor explains the intra-individual differences in sensitivity to corticosteroid effects [26].

The basic principle is best explained by a clinical example. Increasing the daily dose of an ICS from, say, 100 to $200 \mu \mathrm{g}$ will markedly improve its efficacy with little or no increased risk of systemic effects, whereas an increase from, say, 800 to $1600 \mu \mathrm{g}$ will yield little extra efficacy at the expense of a markedly increased risk of systemic side effects.

\section{How do children with asthma grow when they are not treated with inhaled corticosteroids?}

As is the case with any chronic disease, asthma itself may reduce growth. Although this attenuation of growth is highly variable between individual patients, it appears to be related to the severity of the disease, being most pronounced in chronic, poorly controlled asthma. Nevertheless, a reduction in prepubertal growth and a delay in the onset of puberty and the pubertal growth spurt may also be found in wellmanaged and well-controlled asthma [27-30]. The underlying cause of this phenomenon is poorly understood. Studies have shown that although puberty and the pubertal growth spurt occur later than usual, they are not abnormal in any other way, and asthmatic children show catch-up growth later on to reach normal or near-normal adult height $[31,32]$.

\section{What are the effects of inhaled corticosteroids on growth in asthmatic children? Retrospective studies}

The difference in growth between children with mild and severe asthma complicates the interpretation of any retrospective data on growth in asthmatic children being treated with ICS's. In 1981, LiTTLEWOOD et al. [33] were the first to report slower growth in asthmatic children being treated with ICS's. They retrospectively compared height standard deviation scores (SDS) of 249 children with asthma being treated with inhaled bronchodilators or cromolyn sodium, to those of 81 children using BDP, and found that the height SDS scores of children on ICS's were on average 0.5 lower than those on bronchodilators or cromolyn. However, because in the late 1970s and early 1980s ICS's were only given to children with severe asthma, it is quite possible that the slower growth in the ICS group was due to the more severe asthma itself rather than its treatment with ICS. A number of other similarly designed retrospective studies on ICS's and growth in asthmatic children were published subsequently. These studies were summarized in a meta-analysis in 1994 [1]: in the pooled analysis, the effect of ICS's on growth was not statistically significant. It follows from the above that prospective studies are needed to reveal the true effect of ICS's on growth.

\section{What are the effects of inhaled corticosteroids on growth in asthmatic children? Prospective controlled clinical trials}

\section{Short-term studies (weeks)}

A number of well-designed controlled clinical trials have examined the short-term effects of ICS's on growth using knemometry. Since, by using this method, lower leg length can be measured with an accuracy of $0.1 \mathrm{~mm}$, it is uniquely fitted to monitor growth over a period of days to weeks [34]. Although such short-term growth rates do not predict longer term growth in any meaningful way [35], the knemometer is considered to be the most valuable tool in determining short-term ICS systemic side effects [36]. The results of five of these knemometric cross-over studies comparing short-term growth during treatment with and without ICS's are summarized in fig. 4 [37-41]. There is a dosedependent reduction of lower leg growth during short-term treatment with ICS which is most pronounced for BDP. A recent study showed that lower leg growth was less suppressed during a 4 week treatment period with BUD $(800 \mu \mathrm{g} \cdot$ day $)$ when it was given in a single daily dose compared to when it was divided into two doses of $400 \mu \mathrm{g}$ each [42], supporting the hypothesis that the effects of ICS's on growth may be less pronounced during once daily dosing than with twice daily dosing [5].

\section{Medium-term studies (months)}

Ten controlled clinical trials studying the effects of ICS's on growth during several months have been published to date (table 2). Four studies compared BDP $400 \mu \mathrm{g} \cdot \mathrm{day}^{-1}$ to other treatments (theophylline, salmeterol, or placebo). Despite the differences in study design, drug used in the control group, inhaler device used and age range, the results of these studies were 


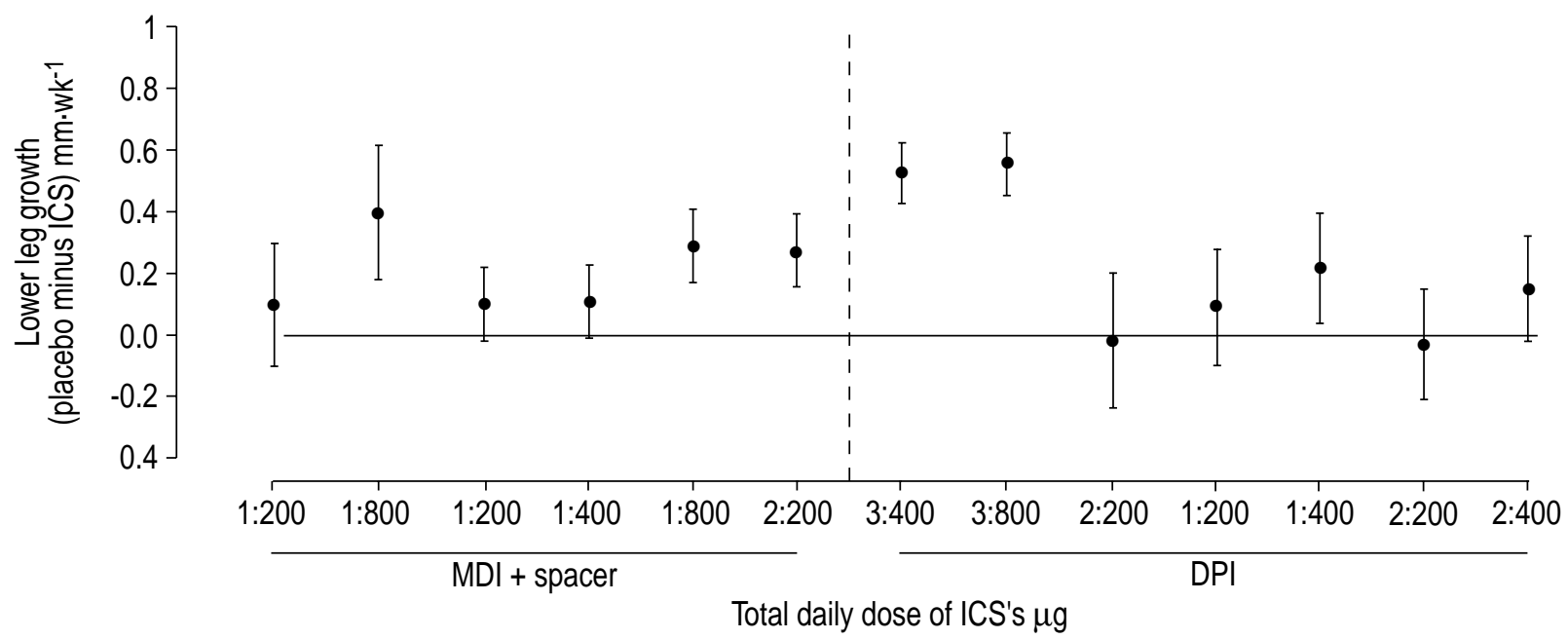

Fig. 4. - Summary of results of knemometric growth studies during short-term therapy (2-8 weeks) with inhaled corticosteroids (ICS's) or placebo. Results are given as mean lower leg growth rate $\left(\mathrm{mm} \cdot \mathrm{wk}^{-1}\right)$ with $95 \%$ confidence intervals. Values above zero indicate reduced lower leg growth during ICS therapy. Daily doses are presented as ICS: dose. 1: budesonide; 2: fluticosone propionate; 3: beclomethason dipropionate; MDI: metered dose inhaler; DPI: dry powder inhaler.

remarkably consistent: children using BDP grew significantly slower (up to $1.8 \mathrm{~cm} \cdot \mathrm{yr}^{-1}$ ) than children from the control group [43-46]. Such a growth retarding effect was not found in two studies comparing BUD by MDI and spacer to other maintenance therapies over months to years of follow-up [47, 48]. However a small, but statistically significant, reduction in growth velocity was found during one year maintenance therapy with BUD inhalation suspension, (table 2) [49]. Similarly, a recent study showed that the growth of children during the first year of treatment with BUD by DPI was $1.1 \mathrm{~cm}$ less than that of children using placebo or nedocromil [50]. Interestingly, this small reduction in growth velocity during the first year of therapy did not persist during further follow-up 4-6 years [50]. It appears, therefore, that the effects of ICS's on growth velocity are temporary.

One open-label study compared growth rates between $1 \mathrm{yr}$ maintenance therapy with FP $\left(100 \mu \mathrm{g} \cdot \mathrm{day}^{-1}\right)$ and that with cromolyn. Although the patients from the FP group grew on average $0.5 \mathrm{~cm} \cdot \mathrm{yr}^{-1}$ slower than children from the cromolyn group, the difference was not statistically significant [51]. Another study comparing growth in asthmatic children treated for $1 \mathrm{yr}$ with placebo and FP (100 and $200 \mu \mathrm{g}$ daily) reported no significant overall difference in growth rates between groups [52]. However, when the difference in growth rates between each of the two FP groups

Table 2. - Controlled clinical trials examining growth during maintenance therapy with inhaled corticosteroids over a period of $>6$ months

Difference in height growth between ICS and

\begin{tabular}{|c|c|c|c|c|c|}
\hline Compound & Reference & Age yr & $\begin{array}{l}\text { Follow-up } \\
\text { months }\end{array}$ & $\begin{array}{l}\text { Treatment in } \\
\text { control group }\end{array}$ & $\begin{array}{l}\text { control group Mean } \\
(95 \% \mathrm{CI})^{\top} \mathrm{cm} \cdot \mathrm{yr}^{-1}\end{array}$ \\
\hline Beclomethasone $400 \mu \mathrm{g}$ daily & [43] & $6-18$ & 12 & Theophylline & $-1.6(-1.94--1.26)$ \\
\hline Beclomethasone $400 \mu \mathrm{g}$ daily & [44] & $7-9$ & 7 & Placebo & $-1.0(-1.36--0.64)$ \\
\hline Beclomethasone $400 \mu \mathrm{g}$ daily & [45] & $6-16$ & 12 & Salmeterol & $-1.4(-2.13--0.67)$ \\
\hline Beclomethasone $400 \mu \mathrm{g}$ daily & [46] & $6-14$ & 12 & $\begin{array}{l}\text { Salmeterol } \\
\text { Placebo }\end{array}$ & $\begin{array}{l}-1.44(-1.60--1.28) \\
-1.08(-1.25--0.91)\end{array}$ \\
\hline Budesonide $600 \mu$ g daily & [47] & $6-16$ & 22 & Placebo & $0.27(-0.86-1.41)$ \\
\hline Budenoside $400-800 \mu \mathrm{g}$ daily & [48] & $3-11$ & $36-72$ & $\begin{array}{c}\text { Cromolyn } \\
\text { Theophylline } \\
\beta_{2} \text { agonist }\end{array}$ & $-0.1(-0.28-0.04)$ \\
\hline Budesonide $500-1000 \mu \mathrm{g}$ daily & [49] & $0.5-8$ & 12 & $\begin{array}{c}\text { Theophylline } \\
\beta_{2} \text { agonist } \\
\text { Cromolyn }\end{array}$ & $-0.84(-1.51--0.17)$ \\
\hline Budenoside $400 \mu \mathrm{g}$ daily & {$[50]$} & $5-12$ & $48-72$ & $\begin{array}{l}\text { Nedocromil } \\
\text { Placebo }\end{array}$ & $\begin{array}{l}-1.0(-0.67--1.33) \\
-1.1(-0.77--1.43)\end{array}$ \\
\hline Fluticasone $100 \mu \mathrm{g}$ daily & [51] & $4-10$ & 12 & Cromolyn & $-0.5(-1.0-0.1)$ \\
\hline $\begin{array}{l}\text { Fluticasone } 100 \mu \mathrm{g} \text { daily } \\
\text { Fluticasone } 200 \mu \mathrm{g}\end{array}$ & [52] & $4-12$ & 12 & Placebo & $\begin{array}{l}-0.21(-0.53-0.11) \\
-0.42(-0.71--0.13)\end{array}$ \\
\hline
\end{tabular}

CI: confidence interval. ICS: inhaled corticosteroid(s); ${ }^{\bullet}$ : values below and above zero indicate reduced and improved growth during ICS therapy versus the control group. 
Table 3. - Results of studies examining adult height in children receiving long-term treatment with inhaled corticosteroids

\begin{tabular}{|c|c|c|c|c|}
\hline Reference & $\begin{array}{l}\text { Number of } \\
\text { children }\end{array}$ & $\begin{array}{l}\text { Age at start } \\
\text { of ICS therapy }\end{array}$ & $\begin{array}{l}\text { Compound used } \\
\text { and daily dose }\end{array}$ & Final height \\
\hline [30] & 26 & $4-10 \mathrm{yrs}$ & $\mathrm{BDP} 400-600 \mu \mathrm{g}$ & Unaffected \\
\hline [4] & 18 & Not given & Not given & $\begin{array}{l}\text { Unaffected (mean final height } 0.9 \mathrm{~cm} \text { lower in ICS } \\
\text { group than in control group*, } 95 \% \mathrm{Cl}-0.6-1.2 \mathrm{~cm} \text { ) }\end{array}$ \\
\hline [54] & 142 & $3-14$ yrs & $\begin{array}{l}\text { Budenoside } \\
110-877 \mu \mathrm{g}\end{array}$ & $\begin{array}{l}\text { Unaffected (mean final height minus mean predicted } \\
\text { final height } 0.31 \mathrm{~cm}, 95 \% \text { CI }-0.6-1.2 \mathrm{~cm} \text { ) }\end{array}$ \\
\hline [55] & 42 & $5-18$ yrs & $\begin{array}{l}\text { BDP, dose } \\
\text { not given }\end{array}$ & $\begin{array}{l}\text { Effect of ICS not consistent: final height comparable between } \\
\text { ICS and control groups*; however, difference between adult } \\
\text { height and target height greater in ICS group (mean 0, SD 5.9) } \\
\text { than in control group* (mean } 2.5 \text {, SD } 4.8)(\mathrm{p}=0.03)\end{array}$ \\
\hline [56] & 61 & $6-17$ yrs & $\mathrm{BDP} 300-800 \mu \mathrm{g}$ & $\begin{array}{l}\text { Unaffected (mean difference in adult heioght SD scores } \\
\text { between ICS and control group 0.14, 95\% CI }-0.38-0.65 \text { )* }\end{array}$ \\
\hline [32] & 97 & $8-20 \mathrm{yrs}$ & $\begin{array}{l}\text { BDP, BUD, } \\
\text { FP } 100-400 \mu \mathrm{g}\end{array}$ & $\begin{array}{l}\text { Unaffected (mean (SD) difference between adult height } \\
\text { and target height for ICS group } 2.6(4.9) \mathrm{cm} \text {, for control } \\
\text { group } 2.5(4.9) \mathrm{cm} \text {; mean difference in adult height between } \\
\text { ICS and control group } 0.8 \mathrm{~cm}, 95 \% \text { CI }-0.1-1.6 \mathrm{~cm})\end{array}$ \\
\hline
\end{tabular}

separately compared to placebo were analysed, the group using the higher dose $(200 \mu \mathrm{g}$ daily) showed significantly reduced growth of $0.42 \mathrm{~cm} \cdot \mathrm{yr}^{-1}$ (table 2). Similar results were reported in a meta-analysis on the effects of fluticasone on growth [53].

\section{Long-term studies (final height)}

Even if ICS treatment does reduce growth in the short-term or the medium-term, it is entirely conceivable that this effect is only temporary, like the effect of the disease asthma itself, and that final adult height is unaffected. From the few studies published on adult height in asthmatic patients being treated with ICS's, this appears to be the case $[4,30-32,54-56]$. The results of these studies are summarized in table 3 . It should be stressed that the numbers of patients in these studies were small and that most studies were retrospective [4, 55, 56]. Moreover, the use of a control group of asthmatics not using ICS's may not be valid because it is likely that the children in the ICS treatment group had more severe asthma than the children in the control group, which may have affected their growth and final height. Given the reassuring results from most of the studies presented in table 3, it is acceptable to conclude that at present there is no evidence that ICS's reduce final attained height. It is important to emphasize that this appears to be true not only in hospital-based populations of moderate-to-severe asthmatics $[4,30,54-56]$, but also in a general population-based study of mild asthmatics [31, 32]. Thus, even in mild asthmatics, in whom the risk of systemic side effects is considered to be greatest [15, 17], there does not appear to be a detrimental effect of longterm ICS therapy on final adult height.

\section{Applicability of the evidence to the individual case}

The evidence presented above suggests that although ICS (particularly BDP) treatment may suppress short- and medium-term growth in children with asthma, the effect is probably temporary. Indeed, in two studies, growth was reduced during the first year of ICS therapy as compared to children not treated with ICS's, but the growth during this first year of therapy was not associated with final height, and no effect of ICS's on final height was found $[50,54]$. Thus, even if ICS's are used for many years, it is unlikely that they cause permanent growth retardation or reduced adult height in asthmatic children.

A second justified conclusion is that the effects of ICS therapy on growth over a period of weeks to months are dose-dependent. Higher doses should be used with caution in any patient, as they only improve efficacy slightly, but increase the risk of side effects (including reduced growth) quite substantially (fig. 3). In patients not doing well on high doses of ICS's, it is important to consider poor compliance, faulty inhalation technique [57] or alternative diagnoses [58] before increasing the dose any further.

It is important to emphasize that the overall evidence arguing against a clinically relevant and persistent growth retarding effect of ICS's in childhood asthma, does not exclude a clinically relevant growth retarding effect of ICS's in an individual case such as this. Case reports have been published showing serious growth suppression during maintenance therapy with BDP [59, 60] BUD [61] and FP [62]. Although the risk of such growth suppression is higher when high doses of ICS's are used, clinically significant growth suppression may occur at any dose of ICS in any patient. This suggests that reduced growth during ICS therapy is an idiosyncratic event - the result of increased individual sensitivity of the particular patient to the systemic side effects of corticosteroids. If the mechanisms underlying this phenomenon (probably involving a glucocorticoid receptor polymorphism [26]) are unravelled, such patients may, in the future, be identified before they experience serious side effects of steroid therapy.

There is accumulating evidence that growth suppression occurs primarily during the first $3-12$ months of ICS therapy $[50,54,63]$. Thus, if a patient grows well during the first 6 months of ICS therapy, the risk of this patient developing growth suppression subsequently is 
small. It is important, however, to continue to monitor growth in all asthmatic children using ICS's. Only then can the individual cases of delayed onset of puberty or significant growth retardation be identified.

\section{So what about the patient?}

Considering all the above, how should we interpret the patient's growth curve? The reduction of growth velocity appears to commence at the age of 8 , at about the time ICS therapy was started. Over the 5 years that followed, her height standard deviation score (SDS) went from around zero (the population mean) to -1.45 at the age of 13. A reduction in height growth of more than $0.25 \mathrm{SDS} \cdot \mathrm{yr}^{-1}$ is considered by paediatric endocrinologists to be clinically significant, and to warrant further investigation [64].

At physical examination, the girl was apparently in good health. There were no signs of puberty (Tanner stages P1 M1) and her breath sounds were clear; there was no wheezing. Further physical examination was unremarkable. Her bone age was 11.5 yrs according to the Tanner \& Whitehouse method.

The conclusion was that the patient's growth was retarded due to a delayed onset of puberty, as may be seen in up to $50 \%$ of asthmatic children [30]. Other than the concurrence in time, there was no particular reason to assume that her slow growth was in any way related to the ICS therapy. It was decided to continue the patient's ICS therapy, and she was switched from BDP to FP by DPI ( $200 \mu \mathrm{g}$ daily). She turned down the offer to have her puberty induced medically. Further followup proved her right, as puberty developed spontaneously shortly afterwards and she showed a normal (though delayed) pubertal growth spurt. At follow-up recently, at the age of 16 , her height was $170 \mathrm{~cm}$ - well within her target height range (fig. 5).

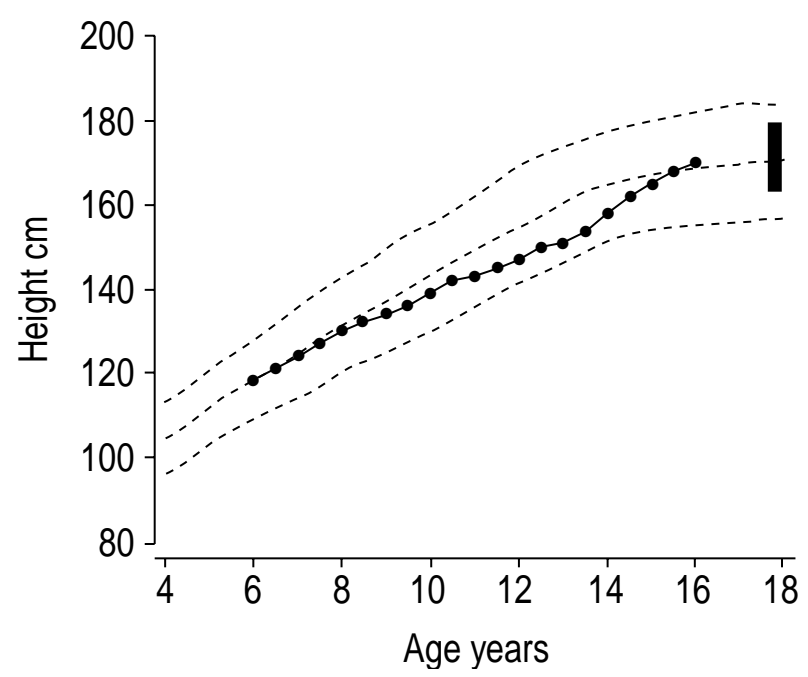

Fig. 5. - Growth curve of Linda the patient at the age of 15 . She still used beclomethansone $400 \mu \mathrm{g} \cdot \mathrm{day}^{-1}$. Growth curve shows typical delayed pubertal growth spurt with catch-up growth towards normal height. Thick black bar represents the target height range. The dotted lines represent the normal mean height \pm 2 standard deviations.

\section{Conclusion}

Although there is consistent evidence that inhaled corticosteroids reduce short-term growth and reduce growth velocity by approximately $1 \mathrm{~cm} \cdot \mathrm{yr}^{-1}$ during the first year of treatment, at present there is no reason to assume that maintenance therapy with inhaled corticosteroids in "normal" daily doses (up to $400 \mu \mathrm{g} \cdot \mathrm{day}^{-1}$ for beclomethasone diproprionate or budesonide, or $200 \mu \mathrm{g} \cdot \mathrm{day}^{-1}$ for fluticasone proprionate) causes clinically relevant growth suppression or reduced final height in the overall majority of patients. Because idiosyncratic responses (increased sensitivity to the systemic effects of inhaled corticosteroids) cannot be ruled out in the individual patient, careful monitoring of growth during inhaled corticosteroid therapy in children with asthma is recommended. If height growth is reduced by more than 0.25 standard deviation score $\mathrm{yr}^{-1}$, further investigation is warranted. The most common cause for prepubertal growth suppression in asthmatic children using inhaled corticosteroids is delayed onset of puberty (as was the case in the patient). This can be easily diagnosed by physical examination and determination of bone age. Even in the rare event of a truly clinically relevant growth suppression due to inhaled corticosteroid therapy, the reasons to continue therapy (well controlled asthma) almost always outweigh the reasons to withdraw treatment (slower growth). Fear of reduced growth velocity should not be a reason to withhold or withdraw this highly effective treatment in asthmatic children, and the American Food and Drug Administration class label warning should be adjusted accordingly.

\section{References}

1. Allen DB, Mullen M, Mullen B. A meta-analysis of the effect of oral and inhaled corticosteroids on growth. J Allergy Clin Immunol 1994; 93: 967-976.

2. Oberger E, Engstrom I, Karlberg J. Long-term treatment with glucocorticoids/ACTH in asthmatic children. III. Effects on growth and adult height. Acta Paediatr Scand 1990; 79: 77-83.

3. Nassif E, Weinberger M, Sherman B, Brown K. Extrapulmonary effects of maintenance corticosteroid therapy with alternate-day prednisone and inhaled beclomethasone in children with asthma. J Allergy Clin Immunol 1987; 80: 518 - 529.

4. Silverstein MD, Yunginger JW, Reed CE, et al. Attained adult height after childhood asthma: effect of glucocorticoid therapy. J Allergy Clin Immunol 1997; 99: 466-474.

5. Allen DB. Influence of inhaled corticosteroids on growth: a pediatric endocrinologist's perspective. Acta Paediatr 1998; 87: 123 - 129.

6. Russell G, Ninan TK. Inhaled corticosteroid toxicity, growth and asthma. In: David TJ, ed. Recent Advances in Paediatrics 18. Edinburgh, Churchill Livingstone 1999; 17: 1-15.

7. Pedersen S, O'Byrne PM. A comparison of the efficacy and safety of inhaled corticosteroids in asthma. Allergy 1997; 52 (Suppl. 39): 1-34.

8. Russell G. Inhaled corticosteroid therapy in children: 
an assessment of the potential for side effects. Thorax 1994; 49: $1185-1188$.

9. Lipworth BJ. New perspectives on inhaled drug delivery and systemic bioactivity. Thorax 1995; 50: $105-110$.

10. Bisgaard H. Aerosol treatment of young children. Eur Respir Rev 1994; 4: 15-20.

11. Newman SP, Millar AB, Lennard-Jones TR, Moren F, Clarke SW. Improvement of pressurized aerosol deposition with nebuhaler spacer device. Thorax 1984; 39: 935-941.

12. Tal A, Golan H, Grauer N, Aviram M, Albin D, Quastel MR. Deposition pattern of radiolabeled salbutamol inhaled from a metered-dose inhaler by means of a spacer with mask in young children with airway obstruction. J Pediatr 1996; 128: 479-484.

13. Newman SP, Moren F, Trofast E, Talaee N, Clarke SW. Deposition and clinical efficacy of terbutaline sulphate from turbuhaler, a new multi-dose powder inhalator. Eur Respir J 1989; 2: 247-252.

14. Wildhaber JH, Devadason SG, Wilson JW, et al. Lung deposition of budesonide from Turbuhaler in asthmatic children. Eur J Pediatr 1998; 157: $1017-$ 1022.

15. Barnes PJ, Pedersen S, Busse WW. Efficacy and safety of inhaled corticosteroids. New developments. Am J Respir Crit Care Med 1998; 157: S1-S53.

16. Selroos O, Halme M. Effect of a volumatic spacer and mouth rinsing on systemic absorption of inhaled corticosteroids from a metered dose inhaler and dry powder inhaler. Thorax 1991; 46: $891-894$.

17. Brutsche $\mathrm{MH}$, Brutsche IC, Munavvar M, et al. Comparison of pharmacokinetics and systemic effects of inhaled fluticasone propionate in patients with asthma and healthy volunteers: a randomised crossover study. Lancet 2000; 356: 556-561.

18. Brattsand R. What factors determine antiinflammatory activity and selectivity of inhaled steroids? Eur Respir Rev 1997; 7: 356-361.

19. Boorsma M, Andersson N, Larsson P, Ullman A. Assessment of the relative systemic potency of inhaled fluticasone and budesonide. Eur Respir J 1996; 9: $1427-1432$.

20. Clark DJ, Clark RA, Lipworth BJ. Adrenal suppression with inhaled budesonide and fluticasone propionate given by large volume spacer to asthmatic children. Thorax 1996; 51: 941 - 943.

21. Donnelly R, Williams KM, Baker AB, Badcock C-A, Day RO, Seale JP. Effects of budesonide and fluticasone on 24-hour plasma cortisol. Am J Respir Crit Care Med 1997; 156: 1746-1751.

22. Lipworth BJ, Clark DJ, McFarlane LC. Adrenocortical activity with repeated twice daily dosing of fluticasone propionate and budesonide given via a large volume spacer to asthmatic school children. Thorax 1997; 52: 686-689.

23. Grahnén A, Eckernäs S-Å, Brundin RM, LingAndersson A. An assessment of the systemic activity of single doses of inhaled fluticasone propionate in healthy volunteers. $\mathrm{Br} J$ Clin Pharmacol 1994; 38: $521-525$.

24. Agertoft L, Pedersen S. A randomized, double-blind dose reduction study to compare the minimal effective dose of budesonide Turbuhaler and fluticasone propionate Diskhaler. J Allergy Clin Immunol 1997; 99: $773-780$.

25. Pedersen S, Hansen OR. Budesonide treatment of moderate and severe asthma in children: a doseresponse study. J Allergy Clin Immunol 1995; 95: 29 33.

26. Huizenga NA, Koper JW, de Lange $\mathrm{P}$, et al. A polymorphism in the glucocorticoid receptor gene may be associated with an increased sensitivity to glucocorticoids in vivo. $J$ Clin Endocrinol Metab 1998; 83: $144-151$.

27. Murray AB, Fraser BM, Hardwick DF, Pirie GE. Chronic asthma and growth failure in children [letter]. Lancet 1976; 2: $197-198$.

28. Martin AJ, Landau LI, Phelan PD. The effect on growth of childhood asthma. Acta Paediatr Scand 1981; 70: 683-688.

29. Chang KC, Miklich DR, Barwise G, Chai H, MilesLarence R. Linear growth of chronic asthmatic children: the effects of the disease and various forms of steroid therapy. Clin Allergy 1982; 12: 369-378.

30. Balfour-Lynn L. Growth and childhood asthma. Arch Dis Child 1986; 61: 1049-1055.

31. Shohat M, Shohat T, Kedem R, Mimouni M, Danon YL. Childhood asthma and growth outcome. Arch Dis Child 1987; 62: $63-65$.

32. Norjavaara E, Gerhardsson de Verdier M, Lindmark B. Reduced height in Swedish men with asthma at the age of conscription for military service. J Pediatr 2000; 137: $25-29$.

33. Littlewood JM, Johnson AW, Edwards PA, Littlewood AE. Growth retardation in asthmatic children treated with inhaled beclomethasone dipropionate. Lancet 1981; 1: $115-116$.

34. Hermanussen M, Geiger-Benoit K, Burmeister J, Sippell W. Knemometry in childhood: accuracy and standardization of a new technique of lower leg measurement. Ann Hum Biol 1988; 15: 1-16.

35. Karlberg J, Gelander L, Albertsson-Wikland K. Distinctions between short- and long-term human growth studies. Acta Paediatr 1993; 82: 631-634.

36. Wolthers OD, Pedersen S. Measures of systemic activity of inhaled glucocorticosteroids in children: a comparison of urine cortisol excretion and knemometry. Respir Med 1995; 89: 347-349.

37. Wolthers OD, Pedersen S. Controlled study of linear growth in asthmatic children during treatment with inhaled glucocorticosteroids. Pediatrics 1992; 89: 839 842.

38. Wolthers OD, Pedersen S. Growth of asthmatic children during treatment with budesonide: a double blind trial. BMJ 1991; 303: 163-165.

39. Wolthers OD, Pedersen S. Short term growth during treatment with inhaled fluticasone propionate and beclomethasone dipropionate. Arch Dis Child 1993; 68: $673-676$.

40. Visser MJ, van Aalderen WMC, Elliott BM, Odink RJH, Brand PLP. Short-term growth in asthmatic children using fluticasone propionate. Chest 1998; 113 : $584-586$.

41. Agertoft L, Pedersen S. Short-term knemometry and urine cortisol excretion in children treated with fluticasone propionate and budesonide: a dose response study. Eur Respir J 1997; 10: 1507-1512.

42. Heuck C, Wolthers OD, Kollerup G, Hansen M, Teisner B. Adverse effects of inhaled budesonide $(800 \mu \mathrm{g})$ on growth and collagen turnover in children with asthma: a double-blind comparison of once-daily versus twice-daily administration. $J$ Pediatr 1998; 133: $608-612$. 
43. Tinkelman DG, Reed CE, Nelson HS, Offord KP. Aerosol beclomethasone dipropionate compared with theophylline as primary treatment of chronic, mild to moderately severe asthma in children. Pediatrics 1993; 92: $64-77$.

44. Doull IJM, Freezer NJ, Holgate ST. Growth of prepubertal children with mild asthma treated with inhaled beclomethasone dipropionate. Am J Respir Crit Care Med 1995; 151: 1715-1719.

45. Verberne AAPH, Frost C, Roorda RJ, van der Laag H, Kerrebijn KF, Dutch Paediatric Asthma Study Group. One year treatment with salmeterol compared with beclomethasone in children with asthma. Am J Respir Crit Care Med 1997; 156: 688-695.

46. Simons FER, Canadian Beclomethasone Dipropionate-Salmeterol Xinafoate Study Group. A comparison of beclomethasone, salmeterol, and placebo in children with asthma. $N$ Engl $\mathrm{J} \mathrm{Med}$ 1997; 337: 1659-1665.

47. Merkus PJFM, van Essen-Zandvliet EEM, Duiverman EJ, van Houwelingen JC, Kerrebijn KF, Quanjer PH. Long-term effect of inhaled corticosteroids on growth rate in adolescents with asthma. Pediatrics 1993; 91: 1121-1126.

48. Agertoft L, Pedersen S. Effects of long-term treatment with an inhaled corticosteroid on growth and pulmonary function in asthmatic children. Respir Med 1994; 88: 373-381.

49. Skoner DP, Szefler SJ, Welch M, Walton-Bowen K, Cruz-Rivera M, Smith JA. Longitudinal growth in infants and young children treated with budesonide inhalation suspension for persistent asthma. J Allergy Clin Immunol 2000; 105: 259-268.

50. Childhood Asthma Management Program Research Group. Long-term effects of budesonide or nedocromil in children with asthma. New Engl J Med 2000; 343: 1054-1063.

51. Price JF, Russell G, Hindmarsh PC, Weller P, Heaf DP, Williams J. Growth during one year of treatment with fluticasone propionate or sodium cromoglycate in children with asthma. Pediatr Pulmonol 1997; 24 $178-186$.

52. Allen DB, Bronsky EA, LaForce GF, et al., Fluticasone Propionate Asthma Study Group.
Growth in asthmatic children treated with fluticasone propionate. J Pediatr 1998; 132: 472 - 477.

53. Sharek PJ, Bergman DA. The effect of inhaled steroids on the linear growth of children with asthma: a metaanalysis. Pediatrics 2000; 106 (1): e8 (http://www. pediatrics.org/cgi/content/full/106/1/e8).

54. Agertoft L, Pedersen S. Effect of long-term treatment with inhaled budesonide on adult height in children with asthma. New Engl J Med 2000; 343: $1064-1069$.

55. van Bever HP, Desager KN, Lijssens N, Weyler JJ, Du Caju MVL. Does treatment of asthmatic children with inhaled corticosteroids affect their adult height? Pediatr Pulmonol 1999; 27: 369-375.

56. Inoue T, Doi S, Takamatsu I, Murayama N, Kameda M, Toyoshima K. Effect of long-term treatment with inhaled beclomethasone dipropionate on growth of asthmatic children. J Asthma 1999; 36: 159-164.

57. Kamps AWA, van Ewijk B, Roorda RJ, Brand PLP. Poor inhalation technique, even after inhalation instruction, in children with asthma. Pediatr Pulmonol 2000; 29: 39-42.

58. Thomas PS, Geddes DM, Barnes PJ. Pseudo-steroid resistant asthma. Thorax 1999; 54: $352-356$.

59. Thomas BC, Stanhope R, Grant DB. Impaired growth in children with asthma during treatment with conventional doses of inhaled corticosteroids. Acta Paediatr 1994; 83: 196 - 199.

60. Wales JKH, Barnes ND, Swift PGF. Growth retardation in children on steroids for asthma. Lancet 1991; 338: 1535.

61. Zwaan CM, Odink RJH, Delamarre-van de Waal HA, Dankert-Roelse JE, Bokma JA. Acute adrenal insufficiency after discontinuation of inhaled corticosteroid therapy (letter). Lancet 1992; 340: $1289-1290$.

62. Todd G, Dunlop K, McNaboe J, Ryan MF, Carson D, Shields MD. Growth and adrenal suppression in asthmatic children treated with high-dose fluticasone propionate. Lancet 1996; 348: 27-29.

63. Doull IJM, Campbell MJ, Holgate ST. Duration of growth suppressive effects of regular inhaled corticosteroids. Arch Dis Child 1998; 78: 172-173.

64. Cole TJ. Do growth chart centiles need a face lift? BMJ 1994; 308: 641-642. 